\title{
Evaluation of Iraqi Rice Cultivars for Their Tolerance to Drought Stress
}

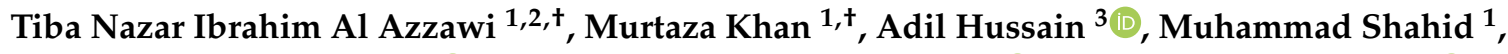 \\ Qari Muhammad Imran ${ }^{1,4} \mathbb{D}$, Bong-Gyu Mun ${ }^{1}$, Sang-Uk Lee ${ }^{1} \mathbb{D}$ and Byung-Wook Yun ${ }^{1, * \mathbb{D}}$ \\ 1 School of Applied Biosciences, Kyungpook National University, Daegu 41566, Korea; \\ redflower660@yahoo.com (T.N.I.A.A.); murtazakhan.bio@gmail.com (M.K.); \\ shahidariswat@gmail.com (M.S.); mimranbot@gmail.com (Q.M.I.); mun0301@naver.com (B.-G.M.); \\ uk0gam@gmail.com (S.-U.L.) \\ 2 Ministry of Agriculture State Company for Agricultural Supplies, Baghdad 10064, Iraq \\ 3 Department of Agriculture, Abdul Wali Khan University, KPK, Mardan 23200, Pakistan; \\ adilhussain@awkum.edu.pk \\ 4 Department of Medical Biochemistry and Biophysics, Umea University, 90187 Umea, Sweden \\ * Correspondence: bwyun@knu.ac.kr; Tel.: +82-(0)53-950-5712 \\ + These authors contributed equally to this work.
}

Received: 17 August 2020; Accepted: 6 November 2020; Published: 13 November 2020

check for updates

\begin{abstract}
Drought stress is a serious problem around the globe and particularly in the Republic of Iraq. Rice is the third most consumed crop for the Iraqi people; however, its cultivation and production is very low due to several challenges including drought. The current study was performed to evaluate five Iraqi rice cultivars along with relevant (drought-tolerant and drought-susceptible) controls under drought stress, either by treatment with 10\% PEG (polyethylene glycol) or through water withholding to induce natural drought stress. The phenotypes of all the cultivars were evaluated and the transcriptional responses of key drought-responsive candidate genes, identified through the EST-SSR marker-based approach, were studied. We also studied transcript accumulation of drought-related transcriptional factors, such as OsGRASS23, OsbZIP12, and OsDREB2A. Moreover, the reference cultivars also included a drought-tolerant inter-specific cultivar Nerica 7 (a cross between Oryza sativa ssp. indica X O. glaberrima). Among the cultivars, the more drought-tolerant phenotypic characteristics and higher transcript accumulation of drought-related marker genes OsE647 and OsE1899 and transcriptional factors OsGRASS23, OsbZIP12, and OsDREB2A were observed in four (out of five) significantly drought-tolerant Iraqi cultivars; Mashkab, followed by Furat, Yasmen, and Amber 33. On another note, Amber Barka was found to be significantly drought susceptible. Mashkab and Amber Barka were found to be the most drought-tolerant and-susceptible cultivars, respectively. The identified tolerant cultivars may potentially serve as a genetic source for the incorporation of drought-tolerant phenotypes in rice.
\end{abstract}

Keywords: rice cultivars; drought stress; transcription factors; chlorophyll content; shoot and root length; qRT PCR

\section{Introduction}

Rice is the staple food of more than three billion people in the world [1], and it plays a key role in food security in Iraq and different countries [2]. Due to its semi-aquatic nature, rice can be cultivated in different ecological conditions, such as rain-fed uplands or lowlands and irrigated lands, depending upon water availability. Its growth and production have been adversely affected by different biotic and abiotic factors, especially drought. 
Drought is considered a natural phenomenon and is commonly defined as a period without significant rainfall (shortage of water), resulting in extensive damage to crops, and an immense loss of yields $[3,4]$. The effect of water-deficiency-causing drought in the Republic of Iraq is a serious problem, which is considered as a major threat to the Middle Eastern countries [5,6]. Different organisms show different responses to environmental stress, depending on age, developmental stage, and previous stress experiences [7]. Different effects occur in plants following stress exposure at different levels, such as molecular, physiological, and biochemical changes, depending on implied factors, including genotype, stress severity, and developmental stage [8,9]. The yield under severe drought stress conditions is significantly reduced by $70 \%$ compared to the yield under normal conditions [10]. Hence, drought mitigation through developing drought-tolerant varieties with higher yields suitable for water-limiting environments is a key factor in improving production once the average yield drops [11]. In the last couple of decades, understanding the mechanism of how plants respond to water deficit stress at a molecular level, as well as a whole plant, has increased [12,13]. Plants show different mechanisms and specific physiologic responses to drought stress including reduced plant growth and productivity, decreased $\mathrm{CO}_{2}$ assimilation, membrane injury and damage of the affected tissues, and in some cases even inhibition of enzyme activity [14]. Plants can adapt to drought stress through drought escape, drought avoidance, and drought tolerance mechanisms [15]. Several drought-responsive genes such as OsGRAS23 [16], DREB2A [17], and bZIPs [18] with their specific roles have been identified in different plants through molecular and genomic analyses, especially in rice. The signaling pathways are induced and different components play their role, such as transducers, stress signals, transcription regulators, and stress-responsive gene expression, after exposure to drought stress [19]. First, stress is perceived by plants, and then specific stress-responsive genes are expressed. According to several investigations, abscisic acid and reactive oxygen species are produced as a response to drought stress, and these compounds induce stomatal closure and stress-responsive gene expression, as well as transcription factors that regulate drought-related genes expression [20]. Different plant species and cultivars that have good natural drought-resistant properties have been recommended by researchers, hoping to reduce drought stress on the lands growing the crops [21,22]. Hence, various rice genotypes with drought tolerance must be identified which can be used for direct cultivation and as gene donors in breeding programs for developing high-yielding drought-tolerant varieties.

Molecular markers are useful for detecting high-degree rice polymorphism [23,24] and are therefore ideal for the studies on genetic diversity. Drought is difficult to manage through conventional phenotypic selection for improving crop yield through marker-assisted selection [25]. It is noteworthy that plant breeding can be developed through molecular marker systems, and the molecular tools have increased the speed and accuracy in getting the desired goals in agriculture. Molecular markers were investigated to significantly detect high-density rice polymorphism [23,24]. Developing molecular markers and using them in genetics are important aspects of studying plant adaptation to drought [26]. Single sequence repeats (SSRs) have been used to evaluate the markers of choice in several areas of genetic diversity studies in rice due to their efficiency, abundance in the rice genome, and high level of polymorphism with reproducible reliable results [27]. The Expressed Sequence Tags (ESTs) can be used as an inexpensive alternative, which is considered as a byproduct of genetic sequence data. They represent transcribed genes that can be developed from another molecular marker, such as SSRs [28]. They are cost-effective and can easily be developed through database mining, using recent bioinformatics tools [29]. Previous studies have shown that the genes OsE647 and OsE1899 are also involved in plant stress responses in various plant species [30,31]. Furthermore, on the bases of a previous study conducted by [32], OsE647 and OsE1899 can be used as a marker gene in studies related to drought stress. Drought stress induces the expression of a series of genes in plants that play a vital role in the stress responses, and their transcription is mostly controlled by transcription factors [33]. In this regard, several TFs have been identified which play a significant role in the regulation of plant responses to stresses [34], such as AP2 TFs including DREB and CBF proteins that bind with dehydration elements to control the transcription of genes involved in stress responses [35]. 
The osmotic stress-induced OsGRASS23, that acts as a TF, and its overexpression enhances resistance of rice to drought stress [16]. Previous studies have shown that various rice $b$ ZIP TFs are also playing a key role in biotic and abiotic stress responses [36]. In the current study, we evaluated the characteristics of Iraqi rice cultivars under drought stress conditions. Furthermore, one of the objectives was to analyze the transcriptional response of plants to water shortage at a significantly early time preferably in hours (for which we analyzed the transcript accumulation of candidate genes identified through EST-SSR-based assessment following drought stress) along with the effects of drought stress at later time points. For this purpose, we evaluated the target varieties using both hydroponic and soil-based approaches. Hence, using the robustness of hydroponics to determine early responses and late responses from soil grown plants.

\section{Materials and Methods}

\subsection{Plant Materials and Growth}

The experiment was conducted during June-July 2019 in the growth chamber and in the greenhouse, at the Kyungpook National University, Daegu, Republic of Korea. A total of 10 rice cultivars of the Japonica and Indica origins were used in the current study. IRAT 112 (O.sativa subsp. indica) [37] and Nagdong (O.sativa subsp. japonica) [38] cultivars were used as the drought-tolerant control, whereas IR64 O.sativa subsp. indica) [39,40] and Ilmi (O.sativa subsp. japonica) [41] were used as the drought-susceptible control. Nerica 7 (a cross between African and Asian (Japonica) origins, i.e., Oryza. sativa (Indica) and O. glaberrima (Japonica) was used as a tolerant cultivar, being well-adapted to upland and lowland ecosystems [42,43]. The list of the candidate and control cultivars is given in Table 1.

Table 1. List of rice cultivars.

\begin{tabular}{ccccc}
\hline Cultivars & $\begin{array}{c}\text { Drought Related } \\
\text { Characteristics }\end{array}$ & Countries & Subspecies & References \\
\hline IR64 & Drought & Philippines & O. sativa ssp. indica & {$[39]$} \\
Irat112 & Dusceptible & Cote dIvoire & O. sativa ssp. indica & {$[37]$} \\
Furat & Unknown & Iraq & O. sativa ssp. indica & {$[44]$} \\
Yasmin & Unknown & Iraq & O. sativa ssp. indica & {$[44]$} \\
Mashkab & Unknown & Iraq & O. sativa ssp. japonica & {$[44]$} \\
Amber 33 & Unknown & Iraq & O. sativa ssp. japonica & {$[44]$} \\
Amber Barka & Unknown & Iraq & O. sativa ssp. indica & {$[44]$} \\
Nerica 7 & Drought Tolerant & Cote dIvoire & Interspecific (O. glaberrima & {$[42]$} \\
ILMI & Drought & Korea & O. sativa ssp. japonica & {$[41]$} \\
Nagdong & Moderate Tolerant & Korea & O. sativa ssp. japonica & {$[38]$} \\
\hline
\end{tabular}

A total of 120 seeds per candidate and control cultivars were surface sterilized in prochloraz solution at a proportion of $125 \mu \mathrm{L} / 250 \mathrm{~mL}$ of distilled water for $3 \mathrm{~h}$ using an electric shaker, followed by rinsing thrice with distilled water for $3 \mathrm{~h}$. The seeds were then germinated on a plate lined with tissue paper at an average temperature of $25^{\circ} \mathrm{C}$ and 16-h/8-h light-dark cycle for $5 \mathrm{~d}$. Thereafter, vigorous and uniform seedlings were transferred to the corresponding medium, either soil or hydroponic culture media for an additional 9 days before exposing them to water-deprived conditions. Finally, 14-day-old rice seedlings were put under drought stress conditions in a growth chamber. To induce PEG (polyethylene glycol)-mediated drought stress, the seedlings were grown in Hoagland solution added with 10\% PEG 6000 (Daejung Chemicals Siheung-si, Republic of Korea) under growth chamber conditions. For the experiments to be conducted in soil trays or pots, horticulture soil was obtained from Hungnong, Republic of Korea. After sterilization, the soil was cooled down to room temperature and filled in plastic trays $(58.5 \mathrm{~cm} \times 28 \mathrm{~cm})$. The trays were then irrigated and covered with transparent 
lids until the soil was saturated with water and ready for transferring the vigorous seedlings. The trays transplanted with the seedlings were then transferred to the greenhouse.

\subsection{Evaluation of Rice Cultivars under PEG and Water-Deprived Conditions}

Two types of approaches were used to assess the response of the cultivars under drought stress. In the first one, plants were subjected to $10 \%$ PEG 6000 as described earlier [45]. Briefly, the germinated seedlings were carefully transplanted in six-well tissue culture plates (SPL Life Sciences Gyeonggi-do, Republic of Korea) containing Hoagland solution [46]. The plants were allowed to acclimatize in these plates for 2 weeks in a growth chamber. After 2 weeks, a modified Hoagland solution, having 10\% polyethylene glycol [47], was added to the plants in the culture plates. Samples for gene expression assessment were taken at 3 and $6 \mathrm{~h}$ after PEG treatment along with the untreated controls for comparison. For symptom development evaluation, the plants were allowed to grow for $14 \mathrm{~d}$ more. Data on root and shoot development and leaf drying percentage was calculated for plants under PEG-induced stress and normal conditions. In the second approach, candidate and control cultivars were also transferred to pots containing soil. The pots were half-filled with water to simulate flooded field conditions. The plants were grown under these conditions for 2 weeks for acclimatization and then subjected to drought stress by draining the remaining water and not watering them for $5 \mathrm{~d}$ [48]. The phenotypes were evaluated and photos were taken from the drought-stressed plants in comparison with the plants growing under normal conditions. The drought-stressed plants were then re-watered to allow recovery for 1 week. After a week, the phenotypic responses were observed, and data on the number of green tillers out of the total tillers were recorded to indicate recovery from drought stress. The cultivars were scored for drought tolerance according to the scale previously described by [49], as shown in Table 2 .

Table 2. Leaf symptoms and corresponding drought score.

\begin{tabular}{|c|c|c|c|}
\hline Scale & Description (Leaf Drying) & Description (Drought Scale) $^{2}$ & Rate \\
\hline 1 & No symptoms of stress effects. & No symptoms & Highly resistant \\
\hline 2 & Slight tip drying. & Slight tip drying & Resistant \\
\hline 3 & $\begin{array}{l}\text { Tip drying extended up to } 1 / 4 \\
\text { length of all leaves. }\end{array}$ & Tip drying extended up to $1 / 4$ & Moderately Resistant \\
\hline 4 & $\begin{array}{l}\text { Tip drying extended to } 1 / 4 \text { length } \\
\text { in at most } 50 \% \text { of all leaves. }\end{array}$ & Tip drying extended up to $1 / 4$ & \\
\hline 5 & $\begin{array}{l}\text { Tip drying extended to } 1 / 4 \text { length } \\
\text { or more in } 50 \% \text { of all leave. }\end{array}$ & $\begin{array}{c}\text { One -fourth to } 1 / 2 \text { of all } \\
\text { leaves dried }\end{array}$ & Moderately susceptible \\
\hline 6 & $50 \%$ of all leaves fully dried. & $\begin{array}{c}\text { One -fourth to } 1 / 2 \text { of all } \\
\text { leaves dried }\end{array}$ & \\
\hline 7 & $\begin{array}{l}\text { More than } 50 \% \text { but less than } 70 \% \\
\text { of all leaves fully dried. }\end{array}$ & $\begin{array}{c}\text { More than } 2 / 3 \text { of all leaves } \\
\text { fully dried }\end{array}$ & Susceptible \\
\hline 8 & $70 \%$ of all leaves fully dried. & $\begin{array}{c}\text { More than } 2 / 3 \text { of all leaves } \\
\text { fully dried }\end{array}$ & \\
\hline 9 & $\begin{array}{l}\text { More than } 70 \% \text { of all leaves } \\
\text { fully dried. }\end{array}$ & All plants apparently dead & Highly susceptible \\
\hline
\end{tabular}

\subsection{Measurement of Chlorophyll Content (SPAD Value)}

The chlorophyll contents in the leaves were measured during and after recovery from the stress period [3,51]. A SPAD meter (SPAD-502., Minolta Co., Ltd., Japan.) was used, following the method previously described [52].

\subsection{Quantitative Real-Time PCR ( $q R T-P C R)$ Analysis}

Total RNA was extracted using the Trizol reagent (Tri-Solution ${ }^{\mathrm{TM}}$, BSK-BIO, Daegu, Republic of Korea) method as per manufacturer standard protocol. About $1 \mu \mathrm{g}$ RNA was used to make complementary DNA using the BioFACT RT kit (BioFACT ${ }^{\mathrm{TM}}$, Daejeon, Republic of Korea). 
The synthesized cDNA was then used as a template in the $\mathrm{Eco}^{\mathrm{TM}}$ real-time PCR machine (Illumina, San Diego, CA, USA) to evaluate the transcript accumulation of selected genes as previously described [53]. A 2X real-time PCR mix (including SYBR ${ }^{\circledR}$ Green I BioFACT ${ }^{\mathrm{TM}}$, Daejeon, Republic of Korea), along with $100 \mathrm{ng}$ of template DNA and $10 \mathrm{nM}$ of each primer in a final volume of $20 \mathrm{~mL}$ was used as reaction mixture for each sample. A no-template control [54] having nuclease-free water instead of template DNA was used as a negative control. A two-step PCR reaction was set up for 40 cycles under the following conditions: polymerase activation at $95^{\circ} \mathrm{C}$ for $15 \mathrm{~min}$, denaturation at $95{ }^{\circ} \mathrm{C}$ for $15 \mathrm{~s}$, annealing, and extension at $60{ }^{\circ} \mathrm{C}$ for $30 \mathrm{~s}$. The melting curves were assessed at $60^{\circ} \mathrm{C}$ for verification of amplicon specificity for each primer pair, and actin was used as the internal reference gene. In this study, we used three key genes (OsbZIP, OsDREB2, and OsGRASS23) related to the drought stress-related TFs and two EST-SSR marker genes (OsE647 and OsE1899) to evaluate the expression of these selected genes under the PEG-induced drought stress. The detailed list of drought-related markers used in this study are given in (Supplementary Table S1).

\subsection{Statistical Analysis}

All the experiments were performed three times. Each time, all the treatments were replicated at least three times. Data from all the replicates of all the experiments were pooled and means were calculated. All the data were statistically analyzed through Duncan's multiple range test (DMRT) using the Statistic Analysis System (SAS 9.1). The level of significance was $p<0.05$. The data was then visualized using GraphPad Prism software (version 6.0, San Diego, CA, USA).

\section{Results}

\subsection{Evaluation of the Rice Cultivars after PEG-Induced Stress}

Our results revealed that after $24 \mathrm{~h}$, the Iraqi rice cultivars Yasmen and Mashkab, together with control cultivar Nerica 7, showed the highest and fastest seed germination, attaining $100 \%$ germination after $48 \mathrm{~h}$, compared with the rest of the cultivars (Supplementary Figure S1). Furthermore, 10\% PEG solution was applied to induce drought stress conditions. The results indicated that the Iraqi rice cultivar Ambar Barka was the most sensitive to PEG-induced drought stress, having a 100\% leaf drying area. However, the drought-sensitive controls IR64 and ILMI showed 33.6\% and 38.3\% leaf drying area, respectively (Figure 1A). On another note, the most tolerant Iraqi cultivars were Mashkab, Furat, and Yasmen, having 6.2\%, 10.4\%, and $12 \%$ leaf drying area, respectively. The drought-tolerant controls, Nagdong, Nerica 7, and IRAT112, exhibited $16.27 \%, 20.5 \%$, and $23 \%$ leaf drying area, respectively (Figure 1A). For visual reference, the leaves of the 10 tested cultivars grown under normal conditions (Hoagland only) and drought stress conditions (modified Hoagland, i.e., Hoagland $+10 \%$ PEG) were photographed (Figure 1B). 

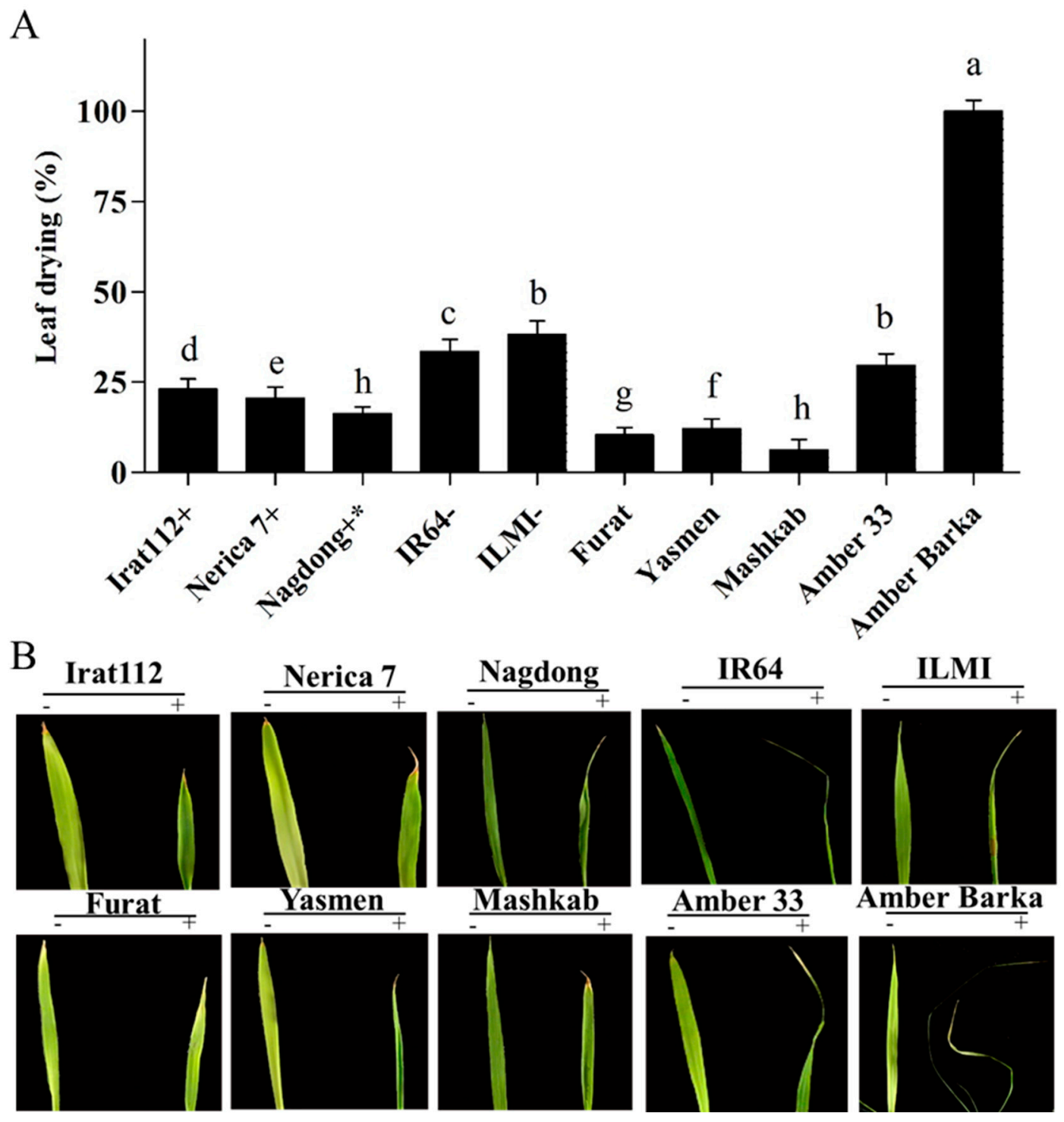

Figure 1. Evaluation of rice cultivars under PEG (polyethylene glycol)-induced stress. Photographs of leaf drying areas of 10 cultivars after exposure to PEG-induced stress continued for $10 \mathrm{~d}$. (A) The symbols $(+),(+*)$, and $(-)$, represent drought-tolerant, moderately drought-tolerant, and drought-susceptible controls respectively. (B) The symbols (-) and (+) represent plants treated and untreated with 10\% PEG. Error bars represent the standard error and each point represents the mean of three replicates. The different letters represent significant differences between the means at $p \leq 0.05$ (DMRT).

The results of the PEG-induced stress also revealed varying degrees of reduction (\%) in shoot lengths of the tested cultivars, compared with plants grown under normal conditions. The maximum shoot length reduction was recorded for the Iraqi cultivar Furat (54\%), followed by ILMI $(28.4 \%)$, then IR64 $(25.3 \%)$. The minimum shoot length reduction was recorded for the cultivar Yasmen $(3.8 \%)$, followed by the drought-tolerant japonica control Nagdong (8.1\%), then Amber Barka (9.5\%). The drought-tolerant indica control (IRAT112) revealed a reduction of $11.7 \%$ in its shoot length under PEG-induced stress conditions. Shoot length reduction data of all the tested cultivars are presented in (Figure 2A). 

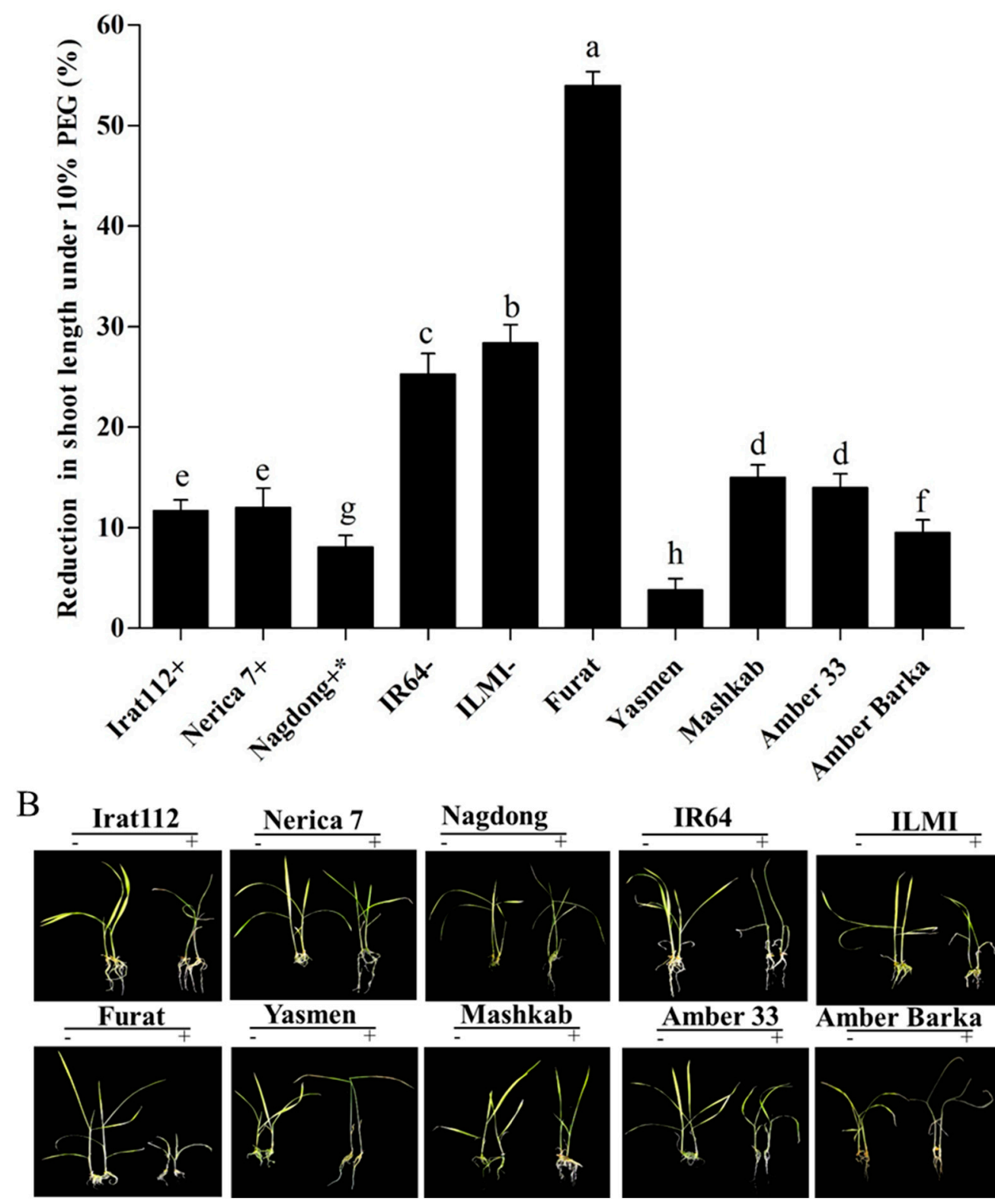

Amber Barka

Figure 2. Shoot length reduction under PEG-induced stress. (A,B) Shoot length reduction of the tested cultivars exposed to PEG-induced stress for $10 \mathrm{~d}$. (A) The symbols $(+),\left(+{ }^{*}\right)$, and $(-)$, represent drought-tolerant, moderately drought-tolerant, and drought-susceptible controls, respectively. (B) The symbols (-) and (+), represent plants treated and untreated with 10\% PEG. Error bars represent the standard error and each point represents the mean of three replicates. The different letters represent significant differences between the means at $p \leq 0.05$ (DMRT).

On another note, PEG-induced stress also resulted in varying levels of root length reduction of all tested cultivars, compared with normally grown plants. The minimum root length reduction was recorded for IRAT 112, with only 1.7\% in comparison to its root length without PEG-induced stress. Among the Iraqi cultivars, Mashkab (6\%) was the least affected cultivar in terms of root length reduction under stress conditions, followed by Yasmen (10\%), and then Amber $33(11.2 \%)$. The drought-sensitive indica control (IR 64) and Amber Barka revealed similar maximum root length reduction (34.7\%), followed by the drought-sensitive japonica control ILMI (31.6\%). The moderately tolerant japonica (Nagdong) cultivar reduced its root length by $17.6 \%$ under the PEG-induced stress. The inter-specific cultivar Nerica 7 (drought-tolerant) had a root length reduction of $8.5 \%$. The results of this parameter are given in (Figure $3 \mathrm{~A}$ ). 


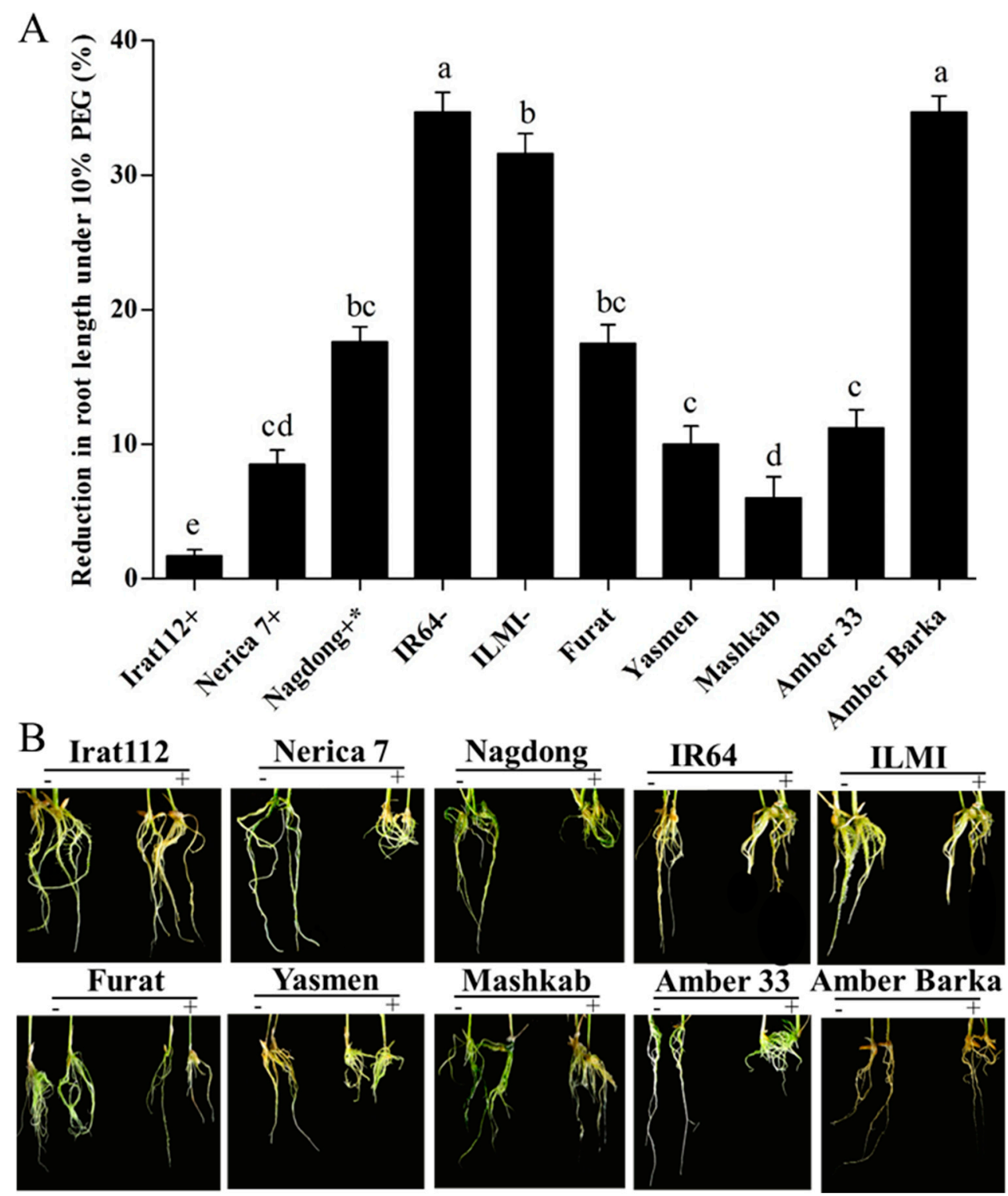

Figure 3. Root length reduction under PEG-induced stress. (A,B) The effects of $10 \%$ PEG on the root length, compared with root lengths under normal conditions. (A) The symbols $(+),\left(+^{*}\right)$, and $(-)$, represent drought-tolerant, moderately drought-tolerant, and drought-susceptible controls, respectively. (B) The symbols (-) and (+), represent plants treated and untreated with 10\% PEG. Error bars represent the standard error and each point represents the mean of three replicates. The different letters represent significant differences between the means at $p \leq 0.05$ (DMRT).

Plants of all the cultivars continuously exposed to PEG-induced stress for $10 \mathrm{~d}$ were transferred to new six-well tissue culture plates, and Hoagland solution was added without $10 \%$ PEG to get the plants out of the stressed conditions to evaluate the cultivars' recovering ability. The 10\%-PEG-treated plants' parametric values were quantified, and the recovery percentage was calculated after the recovery period (7 days). Based on the results, the maximum recovery $(50 \%)$ was attained by the Iraqi cultivar Mashkab, followed by IRAT 112, Furat, and Nerica 7 with $41.6 \%$ each. The minimum recovery percentage was recorded for Amber Barka (8.3\%) and ILMI (16.6\%). Interestingly, the IR64 (drought-susceptible indica control) and the Nagdong (moderately drought-tolerant japonica control) recovered by $25 \%$ each. These results are presented in (Figure $4 \mathrm{~A}$ ). 


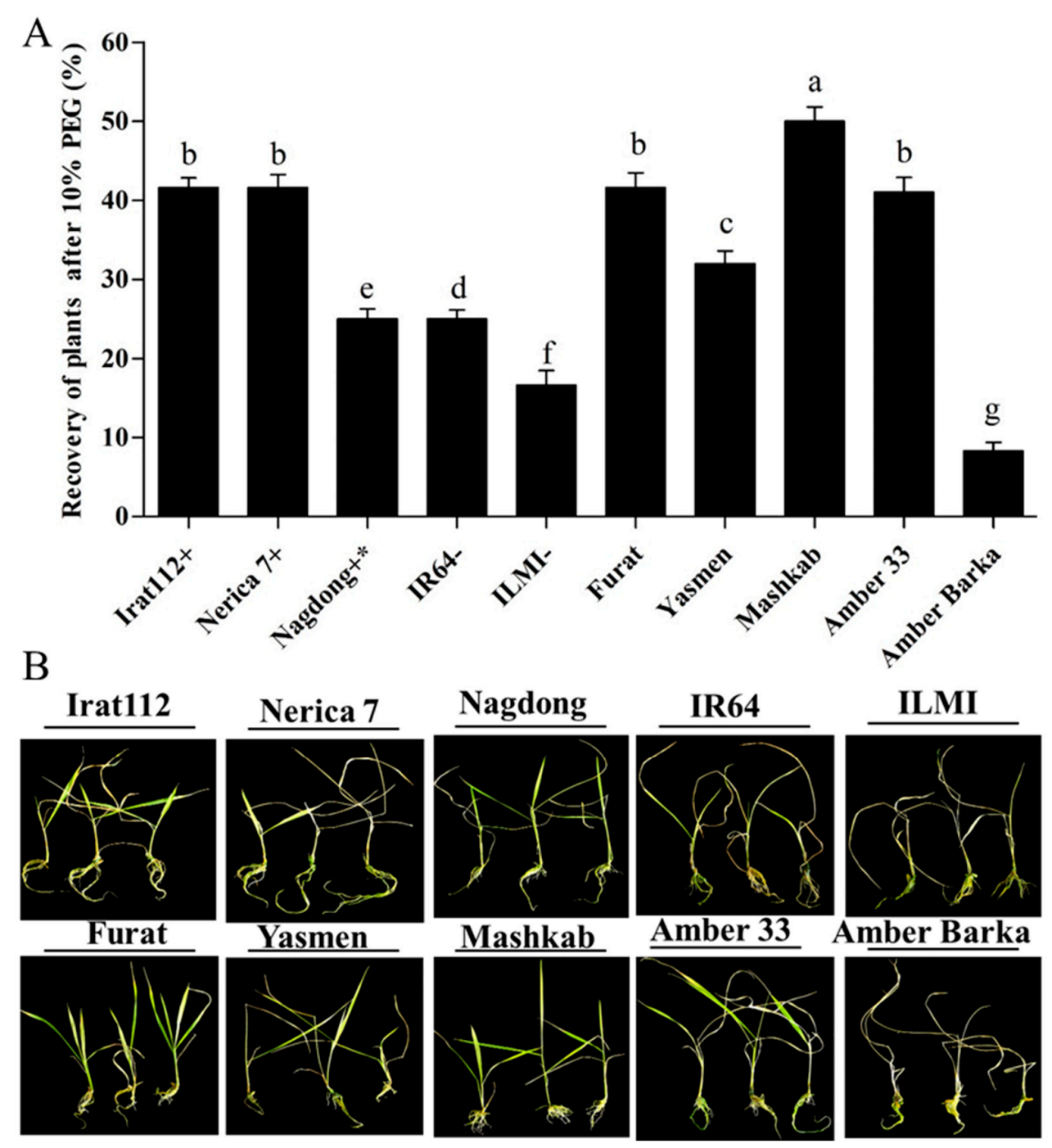

Figure 4. Recovery of plants after PEG-induced drought stress. After exposure to PEG-induced drought stress, plants were grown for $7 \mathrm{~d}$ in Hoagland solution only (without 10\% PEG). (A) Recovery of plants after $10 \%$ PEG treatment. The plants resuming growth were counted in each cultivar, and the recovery percentage was calculated. (B) Phenotypes of the indicated cultivars after recovery. Bars represent the mean data of three replicates for each cultivar. Error bars represent the standard error and each point represents the mean of three replicates. The different letters represent significant differences between the means at $p \leq 0.05$ (DMRT).

\subsection{Molecular Characterization of the Rice Cultivars under PEG-Induced Drought Stress}

The transcript accumulation of the key drought-responsive transcription factor (TF) genes was assessed for the molecular characterization of rice cultivars under PEG-induced drought stress. The results revealed differential expression of the marker genes in the evaluated cultivars. The highest transcript accumulation of the OsbZIP TF gene was recorded for Mashkab at $3 \mathrm{~h}$ of exposure to PEG-induced stress, followed by IRAT112, Amber 33, and Nerica 7. Furat, Yasmen, and Nagdong have increasing trends at 3-6 h post-treatment. Amber Barka and ILMI revealed a lower expression of OsbZIP (Figure 5A). OsDREB2A was another important marker gene that was evaluated. The highest accumulation of OsDREB2A was in Yasmen, followed by Mashkab at $3 \mathrm{~h}$ of the treatment, but the expression was decreased at $6 \mathrm{~h}$ of the treatment (Figure $5 \mathrm{~B}$ ). After $6 \mathrm{~h}$, the transcript accumulation of OsGRASS23 was upregulated in Yasmen and drought-tolerant control Irat112 (Figure 5C). After $3 \mathrm{~h}$, the transcript accumulation of the OsE647 marker gene was higher in Mashkab, followed by Yasmen, Furat, IRAT112, and Nagdong. In the drought-sensitive IR64 and ILMI, OsE647 expression was 
lower. For Amber 33, an increasing trend was observed later at $6 \mathrm{~h}$ of $10 \%$ PEG treatment (Figure 6A). The highest transcript accumulation of the OsE1899 marker gene was revealed for IRAT 112 and Mashkab at $3 \mathrm{~h}$ of PEG treatment, followed by Furat, and Yasmen. Interestingly, the expression of this gene was increased at $3 \mathrm{~h}$ of the treatment while decreased in all of the cultivars at $6 \mathrm{~h}$ of treatment. The expression was lower in drought-susceptible control ILMI, followed by Amber Barka and Amber 33 (Figure 6B).

A

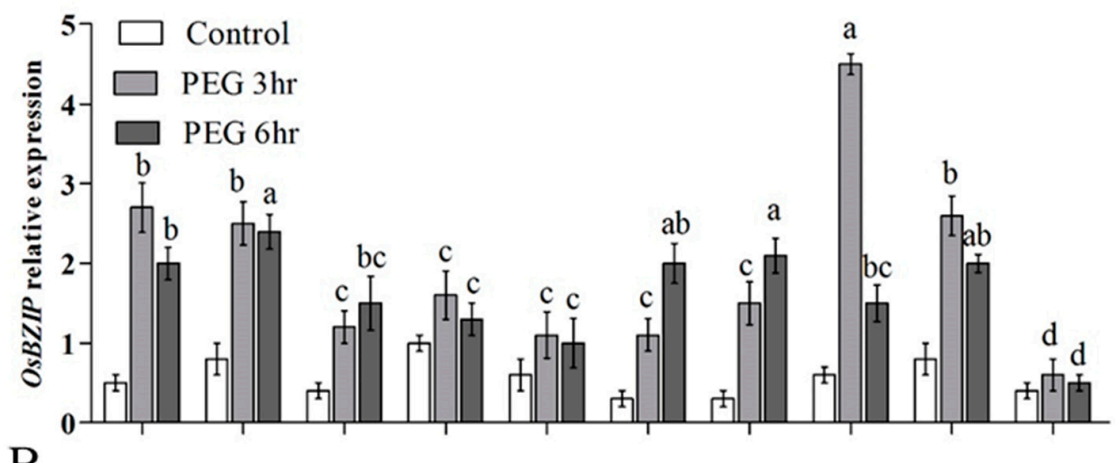

$\mathrm{B}$
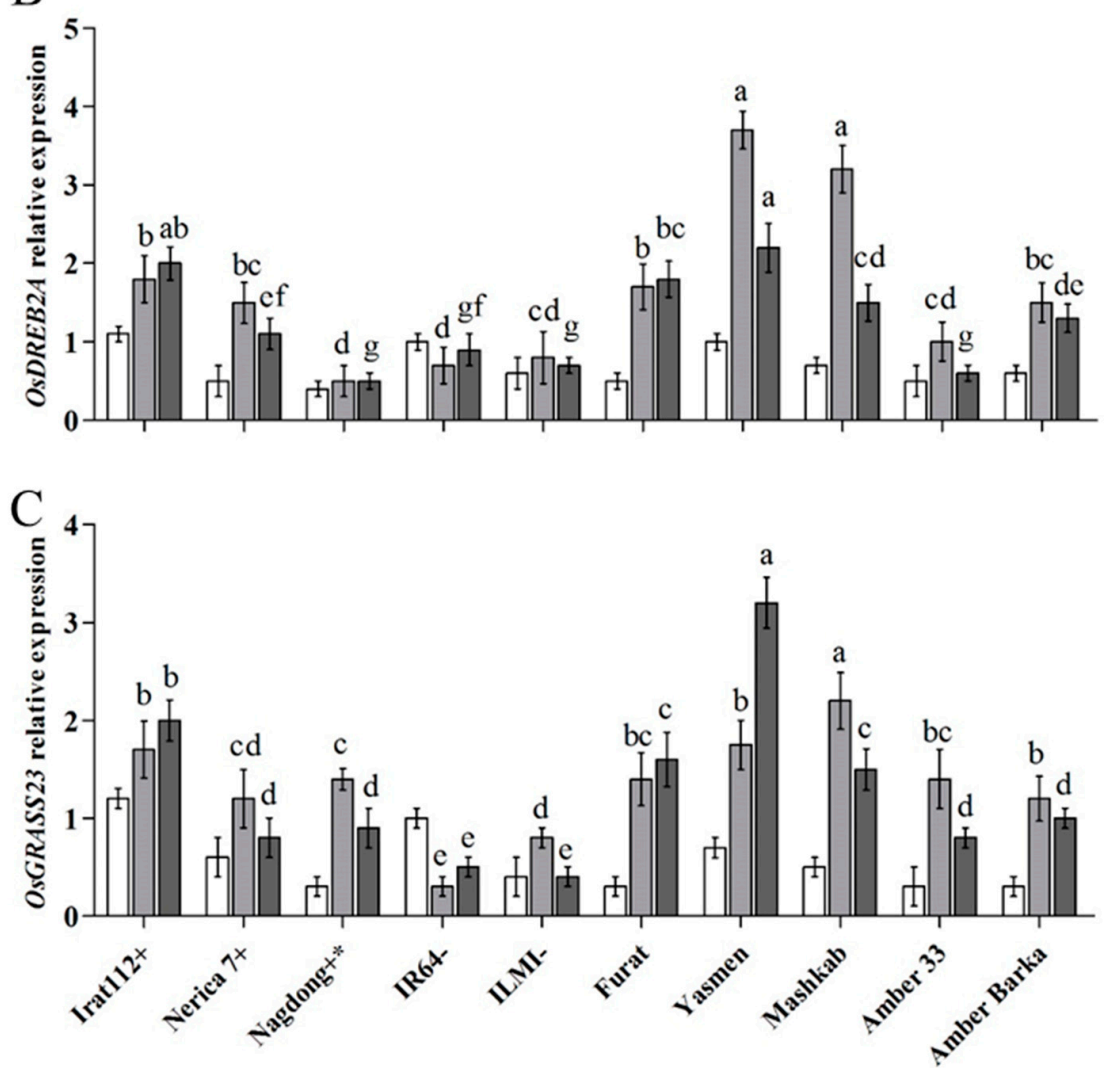

Figure 5. Relative expression of drought-responsive marker genes after PEG-induced stress. Leaf samples were taken from the plants exposed to PEG-induced stress along with plants without exposure (control). The transcript accumulation of the indicated marker genes was assessed using qRT-PCR. Expression data were normalized against the baseline expression level of the genes in IR64 (drought-sensitive control). (A), (B), and (C) reveal the expression profile of the three drought stress-related marker genes OsBZIP, OsDREB2A, and OsGRASS23, respectively. Error bars represent the standard error and each point represents the mean of three replicates. The different letters represent significant differences between the means at $p \leq 0.05$ (DMRT). 


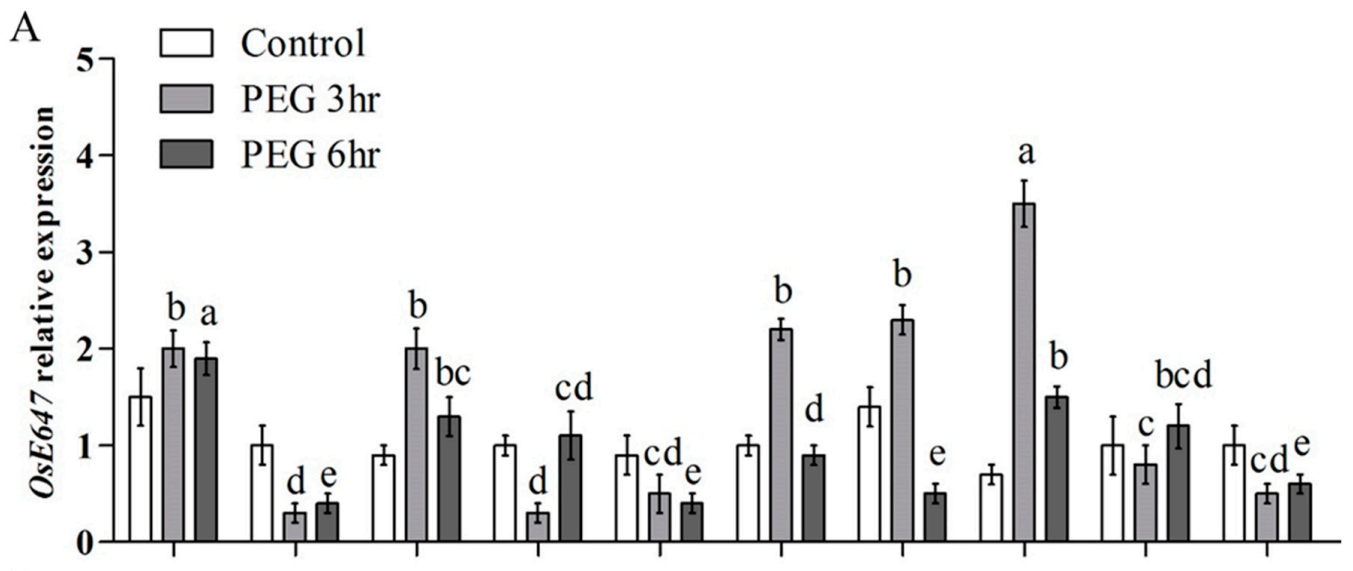

$\mathrm{B}$

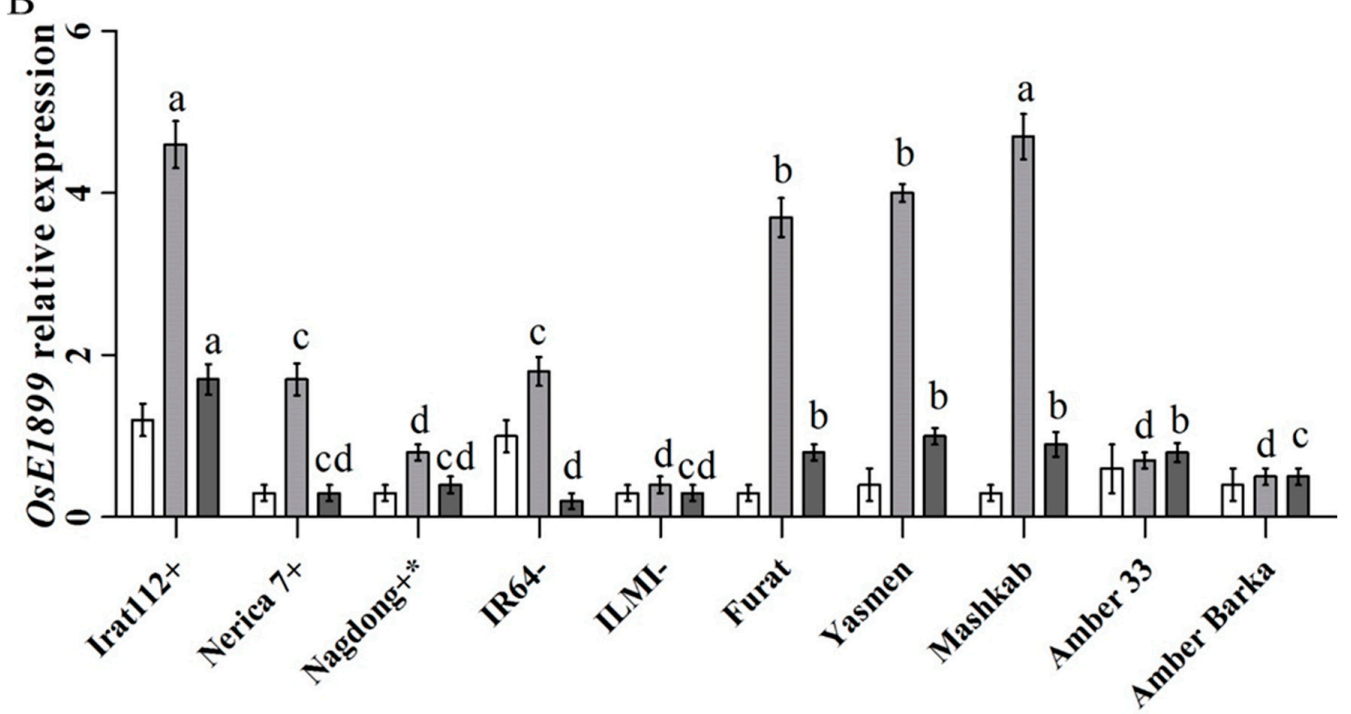

Figure 6. Relative expression of drought-responsive marker genes after PEG-induced stress. Leaf samples were taken from the plants exposed to PEG-induced stress along with plants without exposure (control). The transcript accumulation of the indicated marker genes was assessed using qRT-PCR. Expression data were normalized against the baseline expression level of the genes in IR64 (drought-sensitive control). (A,B) reveal the expression profile of the two drought stress-related EST-SSR markers genes OsE647, and OsE1899, respectively. Error bars represent the standard error and each point represents the mean of three replicates. The different letters represent significant differences between the means at $p \leq 0.05$ (DMRT).

\subsection{Phenotypic Evaluation of Rice Cultivars under Water Deficit Conditions (Greenhouse)}

\subsubsection{Induction of Drought Stress under Greenhouse Conditions}

To evaluate the plants under water deficit conditions to induce the drought stress, plants grown in pots in greenhouse for 15 days after transplantation and submergence in water, were exposed to water deficit by shifting the pots containing plants to dried trays. The plants were deprived of water for $5 \mathrm{~d}$ to induce drought stress. It was observed that among the tested cultivars the drought-tolerant cultivar was Mashkab whereas, the susceptible one was Amber Barka. At $96 \mathrm{~h}$ of water deficit conditions in the greenhouse, drought stress was observable in all the cultivars, and the wilting, rolling, and curling symptoms typical to drought stress were prominent (Figure 7). 


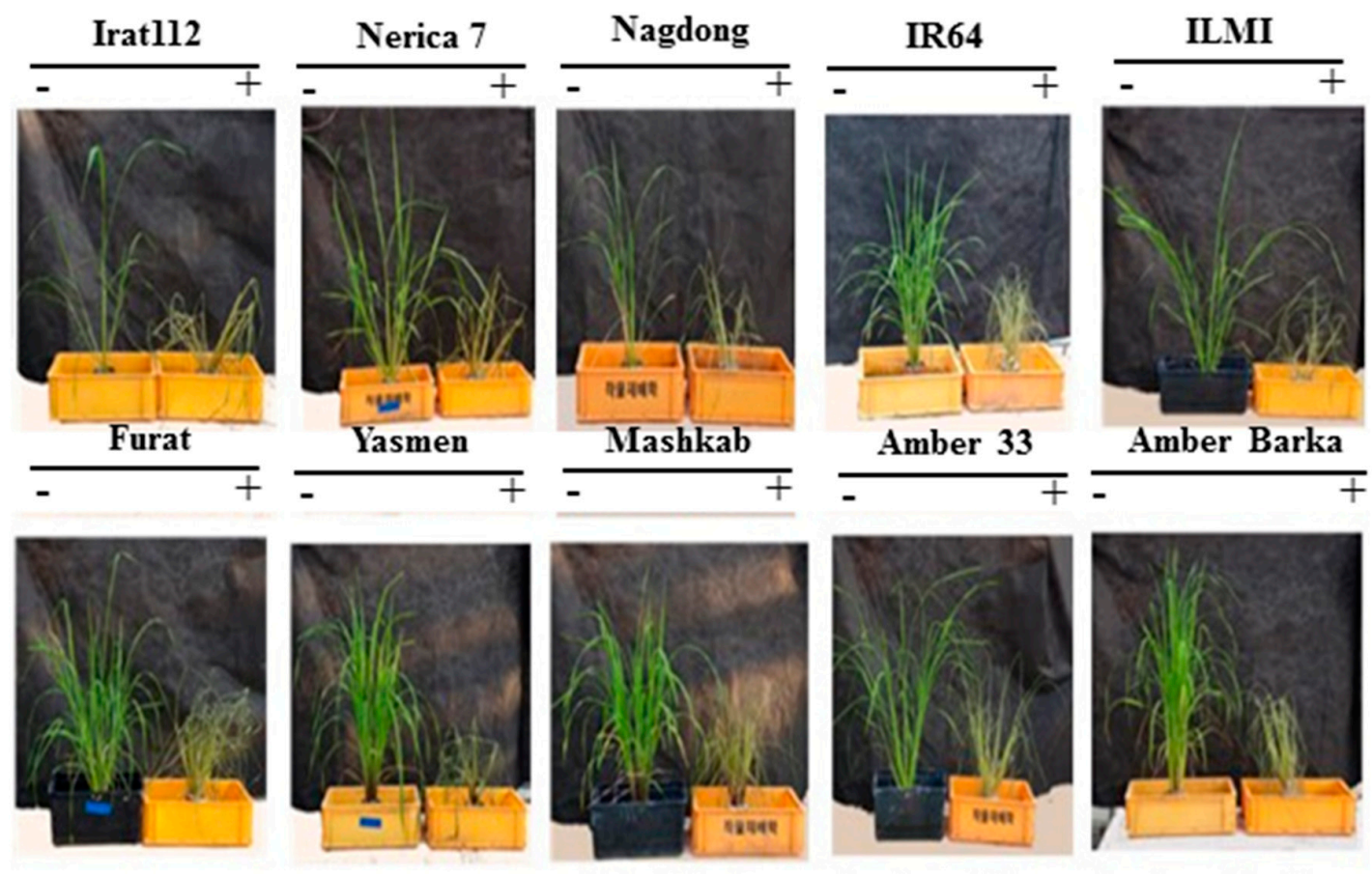

Figure 7. Induction of drought stress under greenhouse conditions. Drought stress was induced in the tested cultivars by creating a water-deprived condition in the greenhouse for 5 days. Typical drought symptoms are evident in all the cultivars. The presented pictures are the representatives of three replicates along with control plants on the left side of each image. The symbols (-) and (+) represent plants treated and untreated with drought stress by water withholding method.

\subsubsection{The Recovery Phase of Drought-Stressed Plants}

After exposure of the plants to drought stress induced by water deficit conditions for $5 \mathrm{~d}$, the plants were re-watered. Plants were monitored for $7 \mathrm{~d}$ as a recovery phase. (Figure $8 \mathrm{~A}$ ) reveals the recovery $(\%)$ in terms of green tillers after the recovery phase for all of the cultivars. Cultivars with less than $50 \%$ recovery were considered as drought-sensitive, otherwise drought-tolerant. Based on the experiment, the Mashkab revealed a maximum recovery of $100 \%$, being the most drought-tolerant cultivar, followed by Furat, Nerica 7, Amber 33, and Nagdong with $85.6 \%, 82.6 \%, 79.5 \%$, and $61.2 \%$ recovery, respectively. ILMI was the most sensitive among the cultivars, with $19 \%$ recovery, whereas IR64 had a 36.8\% recovery. Two cultivars, Yasmen and Amber Barka, also revealed to be sensitive, with $46 \%$ and $41 \%$ recovery, respectively (Figure $8 \mathrm{~A}$ ). All tested cultivars were photographed after the recovery phase along with the control plants for comparison. The images are presented in (Figure $8 \mathrm{~B}$ ) for better visual comparison. 


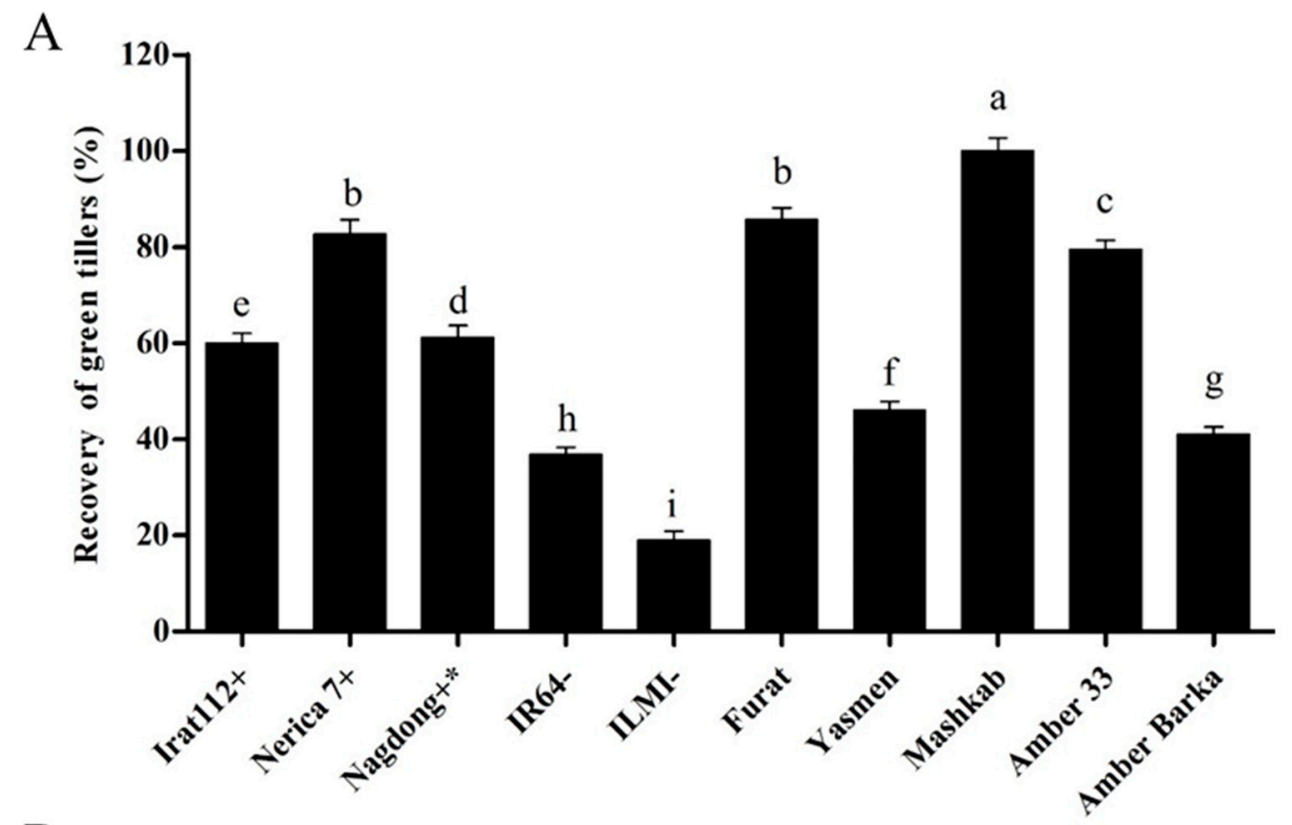

B

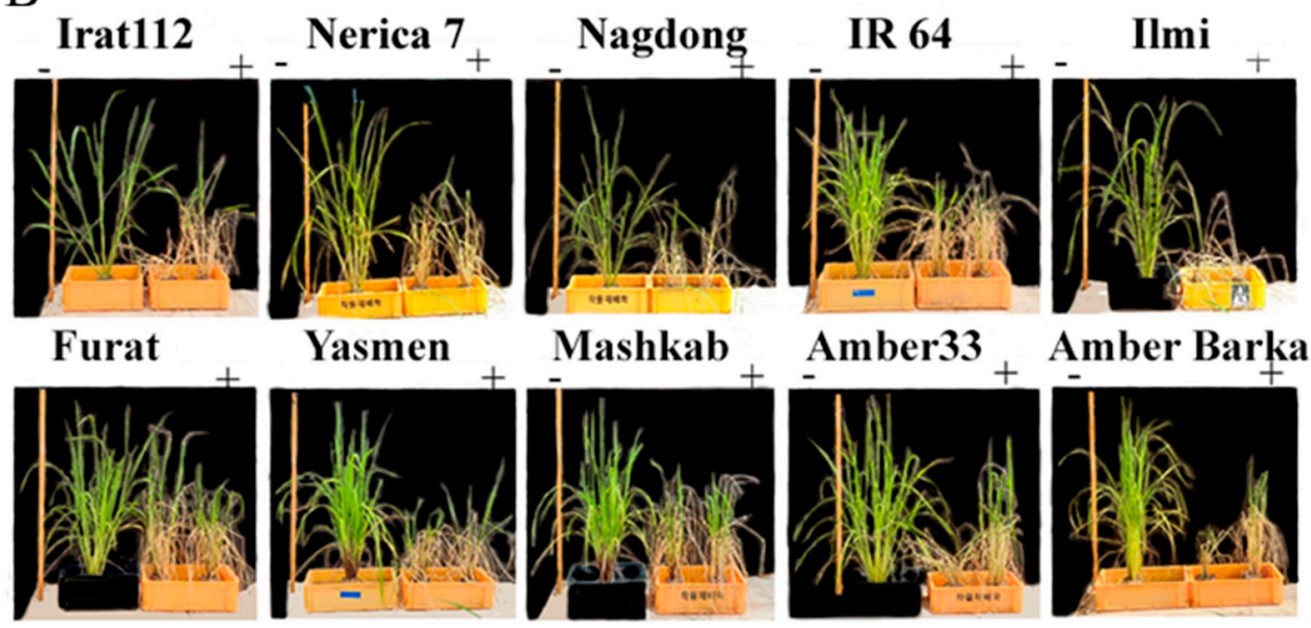

Figure 8. The recovery percentage of the plants after drought stress induced by water withholding. (A) The recovery percentage was calculated as the number of green tillers/recovered tillers out of the total number of tillers in each plant. (B) The recovery phase was continued for $7 \mathrm{~d}$ by submerging the drought-exposed pots containing the plants. The symbols (+), and (-), represent drought-tolerant, moderately drought-tolerant, and drought-susceptible controls, respectively. The symbols (-) and (+), represent treated and untreated plants. Data presented are the mean values of three replicates, and error bars represent the standard error. The different letters represent significant differences between the means at $p \leq 0.05$ (DMRT). The background in panel B was modified for better clarity.

\subsection{Chlorophyll Content of the Plants}

Drought conditions reduced the chlorophyll content of the plants, and that is why in the current experiment, the chlorophyll contents of the drought-stressed plants were measured and compared with the plants grown under normal conditions. The results revealed that the chlorophyll content of the drought-sensitive ILMI cultivar was reduced by $85.3 \%$, compared with plants grown under normal conditions, followed by Nagdong, being drought-tolerant, but a reduction of $52.7 \%$ chlorophyll content was observed. The least affected cultivar in terms of chlorophyll content was Nerica 7 , with an $8.6 \%$ reduction. Mashkab exhibited the least reduction in chlorophyll content among the Iraqi cultivars, 
with only 9.1\% reduction, followed by Furat, Amber 33, and IRAT 112 with $15.3 \%, 19.4 \%$, and 21.5\% reduction, respectively (Figure 9).

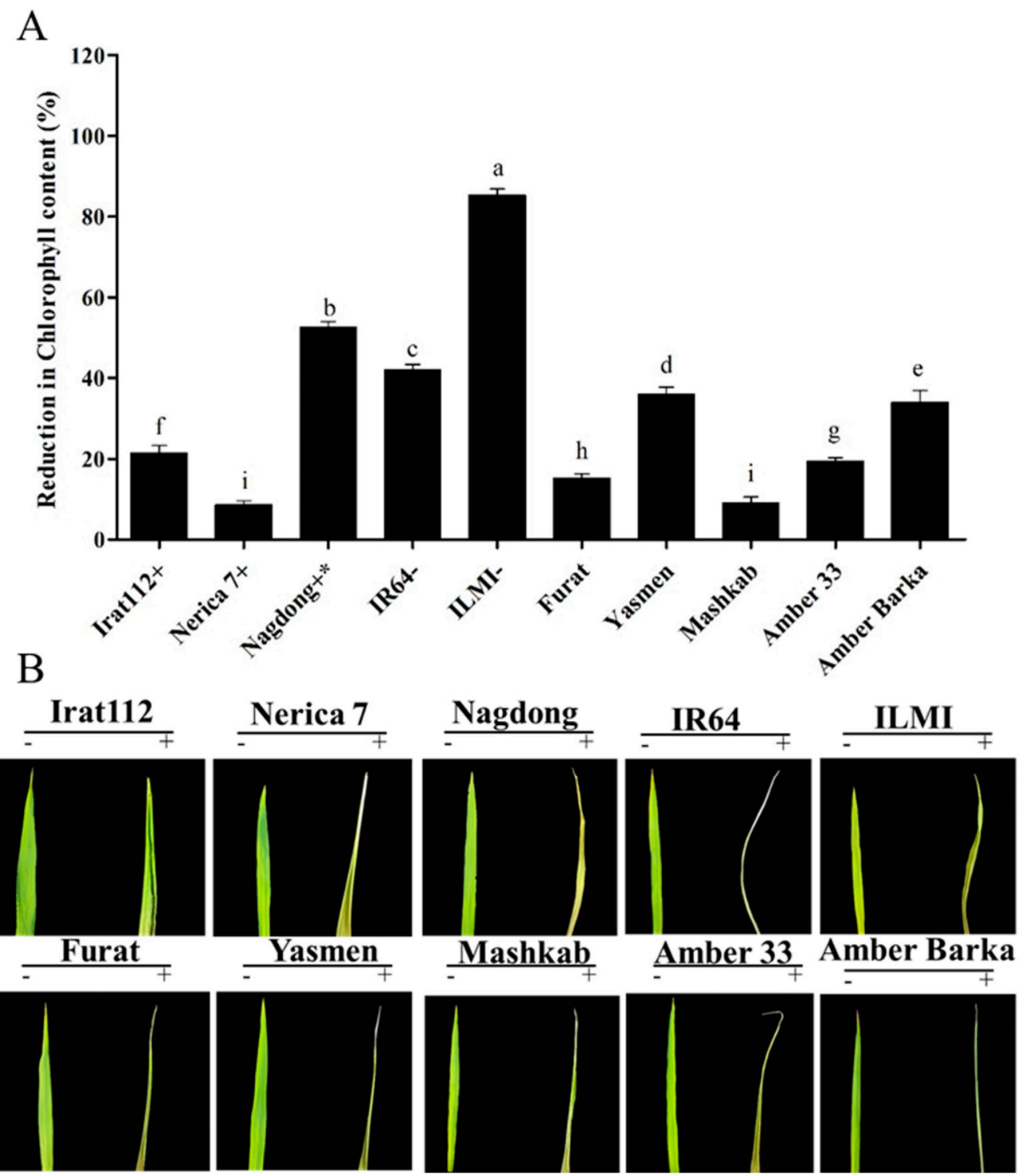

Figure 9. Reduction in chlorophyll content. Chlorophyll content as measured using SPAD for plants grown under normal conditions and then for drought-treated plants. The difference between the two values was calculated as the percent reduction in the chlorophyll content. (A) The symbols $(+),\left(+{ }^{*}\right)$, and $(-)$, represent drought-tolerant, moderately drought-tolerant, and drought-susceptible controls, respectively. (B) The symbols (-) and (+), represent treated and untreated plants. Data presented are the mean values of three replicates, and error bars represent the standard error. The different letters represent significant differences between the means at $p \leq 0.05$ (DMRT). The background in panel B was modified for more clarity.

\section{Discussion}

Drought stress is a major threat to global food security because it adversely affects crop production. Rice is among the major crops grown in Iraq, and it consumes more water in comparison to other crops. Unfortunately, Iraq is on the list of countries that may potentially face a major drought threat in the near future, which has been estimated to result in large-scale famine [55]. Dry seasons often coincide with the winter as well as summer crops in Iraq. In 2018, facing an unusually harsh drought, the agriculture ministry suspended the cultivation of rice, corn, and other cereals, which need large quantities of water. 
The decision slashed the income of rice farmers, who usually earn between 300,000 and 500,000 dinars ( $\$ 240$ to $\$ 400$ ) a year per dunum (https://phys.org/news/2018-07-iraq-treasured-amber-rice-crop.html). The same year, the total area under cultivation was reduced by 50\% (https://www.thenational.ae/world/ mena/iraq-s-cultivated-areas-reduced-by-half-as-drought-tightens-grip-1.756996).

Therefore, it is high time to evaluate existing rice cultivars in Iraq for drought tolerance. The current study was performed to evaluate the drought response of multiple rice cultivars grown commonly throughout Iraq. The results revealed that the Iraqi cultivars Yasmen and Mashkab are the fastest germinating cultivars, as shown in Table 1 , and faster germinating abilities are considered among the desirable traits of crops like rice [56,57]. The plants which show early leaf rolling during drought stress are drought-susceptible as indicated by the level of leaf drying [58]. The Amber Barka revealed to be the most sensitive cultivar among the tested cultivars, in terms of leaf drying percentage, having $100 \%$ drying percentage and rolling of its leaves under PEG-induced drought conditions compared to control conditions (Figure 1A). On another note, Mashkab proved to be tolerant in terms of leaf drying under the stress conditions, as it had only a $6.2 \%$ leaf drying percentage (Figure 1A). In general, the plants challenged with water deficit conditions showed reduced shoot growth and the number of roots [59]. Our results for the shoot reduction percentage suggested that the Yasmin cultivar was least affected whereas Furat the most, among the tested cultivars towards drought stress (Figure 2A). Except for the shoot reduction percentage, other phenotypic evaluation such as leaf drying percentage (Figure 1A,B), root length reduction percentage (Figure $3 \mathrm{~A}, \mathrm{~B}$ ), and recovery percentage from PEG-induced drought condition (Figure $4 \mathrm{~A}, \mathrm{~B}$ ) suggested that Mashkab is the most tolerant while Amber was the most sensitive cultivar among the tested Iraqi cultivars. These traits indicate the tolerance levels of the cultivars, which implies that their drought tolerance response is actively regulated, and the genetic composition of the tolerant cultivars is better than the sensitive cultivars in terms of drought tolerance. The responses of all the cultivars under study to PEG-induced drought stress in a hydroponic culture, and drought stress treatment in a pot experiment have been summarized in Supplementary Tables S2 and S3. Previous reports suggest that drought stress affects seed germination, seedling growth, and other physiological parameters $[39,60,61]$. Root development is significant for plants during adaptation to drought stress since water and nutrients are acquired from the soil or any other nutrient solution in the case of plants grown in a hydroponic medium [62]. Properties, such as root growth and size, are considered the earliest morphological characteristics in selecting drought-tolerant varieties. Other reports also discussed the significance of roots under drought conditions and suggested that roots suffer the ill effects of water deficit more than shoots [63]. Therefore, a deep rooting system is a desirable trait in rice improvement programs under drought stress [64].

The response of different genotypes to drought stress is different depending upon their innate molecular mechanism and thereby the expression and regulation of drought-stressed related genes [65]. We, therefore, sought to determine the transcript accumulation of key drought-related genes associated with drought-related markers (OsE647 and OsE1899) and transcriptional factors (OsBZIP, OsDREB2A, and OsGRAS23). There are a number of genes and/or transcription factors that have reported roles in drought tolerance in rice. A comprehensive detail of these genes is given in a review article by [66]. Based on the availability of marker genes and available resources, we have focused on the transcription factors that are commonly used in drought stress such as OsBZIP, and the novel OsGRAS23 transcription factor. OsBZIP TFs are already known for their role in drought responses. OsDREB2A has been shown to respond to drought stress at an early time point ranging from 40 minutes to 10hrs [67]. OsGRAS23 is a novel drought responsive transcription factor induced by drought, $\mathrm{NaCl}$, and jasmonic acid, and is located in a drought-resistant QTL interval on chromosome 4 of rice [16]. This shows that the genes under study are representative drought-responsive genes. The expression of these genes/TFs was to validate the phenotypic response of the tested cultivars towards drought stress and were not marker-based selection. Our study will help in selection of plant material for such studies for example, and also will help the farmers to prioritize cultivars for growth when a drought condition is expected. Our results suggested that Mashkab shows more transcript accumulation of OsE647 and OsE1899 at 3 
h of PEG treatment (Figure 6A,B) suggesting that the tolerant response of Mashkab might be due to the early induction of transcriptional machinery. This was further confirmed by the high induction of OsbZIP and OsDREB2A, the two important drought-related transcription factors after $3 \mathrm{~h}$ of PEG treatment (Figure 5A,B). The previous research evaluated that OsE647 and OsE1899 are involved in the response to stress in other plant species $[30,31]$. OsGRAS23, a rice GRAS transcription factor gene, is involved in drought stress response through regulating the expression of stress-responsive genes [16]. Transcription factors of the basic leucine zipper [68] family have a significant role in stress mitigation in all eukaryotes. In plants, $b$ ZIPs regulate major development and physiological processes including photomorphogenesis, leaf and seed formation, energy homeostasis, and abiotic and biotic stress responses [18]. The dehydration-responsive element-binding protein2a (DREB2A) transcription factor controls drought-related inducible gene expression and requires post-translational modification for its activation [17]. So, keeping in mind the role of the above drought-related TFs, we measured their expression in all rice cultivars which were used in this study. In the current study, the expression of the above TFs was significantly high in Mashkab, which indicates that this is the most drought-tolerant cultivar and could be a potential source of drought-tolerant genes.

Although there are some statistical similarities in the expression of marker genes between the tolerant check (Nerica 7) and identified susceptible cultivar Amber Barka, the relatively similar expression patterns of markers genes OsE647, and OsE1899 in Ambar Barka and the drought-tolerant check Nerica 7, alone are not enough to warrant drought-tolerance responses in Amber Barka as all the other parameters studied indicated that Ambar Barka is the most susceptible cultivar. It is already known that plant stress responses are regulated at several different levels ranging from phenotypic features to regulation at transcriptional and proteome level. Furthermore, the expression patterns of the above-mentioned makers in Amber Barka are completely different from the other drought-tolerant check Irat112, indicating different mechanisms of drought tolerance in different cultivars.

The effects of drought stress on the chlorophyll content of the plants were a result of photosynthetic efficiency (yield) decrease [69]. Therefore, we were interested to see the reduction in chlorophyll content in both tolerant and sensitive cultivars. We observed that Mashkab exhibited the least chlorophyll content reduction (9.1\%) compared to other tested Iraqi cultivars while Yasmin and Amber Barka showed more reduction in chlorophyll contents (Figure 9A). An overall view of the results indicates that among the cultivars under study Furat, Yasmen, Mashkab, and Amber 33 either performed better than or statistically similar to the drought-tolerant checks for most of the parameters such as the reduction in root length, number of plants recovered following drought stress and the expression of DREB2A, GRASS23, E647, and E189. Furthermore, Mashkab was found to be the most drought-tolerant cultivar with significantly higher values for the different parameters under study. An obvious and interesting feature of the drought-tolerant cultivars under study, the response was found to be most significant after $3 \mathrm{hrs}$ of the treatment than after $6 \mathrm{hrs}$ of the treatment indicating a significantly robust control of drought-responsive mechanisms in these plants. The observed differences in the transcriptional responses at 3 and $6 \mathrm{hrs}$ might be due to the strategy of the plant to reserve metabolic energy for other processes [53]. Therefore, a gene might be induced when is required and may come to basal level after the desired function is completed. Furthermore, the drought-tolerant checks Irat112 and Nerica7 are both indica type. Irat112 was developed in 1983 by hybridization with the mutant variety IRAT13 (obtained by irradiation with chronic gamma rays). Higher tillering, early maturity, and drought tolerance are the main attributes of the variety [70]. Nerica7 (New Rice for Africa) was released in the year 2000 and developed by crossing O. sativa and O. glaberrima (often called African rice). It is one of the eighty-two different upland and lowland African rice varieties adapted for rain-fed or irrigated environments [71].

\section{Conclusions}

Rice is an important cereal that serves an important food source for people all over the world. Though we only tested all the cultivars at an early vegetative growth stage, our results indicate 
that among the tested Iraqi cultivars, Mashkab could be one of the candidates for developing drought-tolerant cultivars. However further detailed investigation is required to unravel the drought-tolerant capabilities of Mashkab cultivar which could be a great help to solve the issues of drought-induced yield reduction in Iraq and in the surrounding Arabian Peninsula.

Supplementary Materials: The following are available online at http://www.mdpi.com/2073-4395/10/11/1782/s1, Figure S1: Seed germination was evaluated for the indicated cultivars belonging mainly to the indica and japonica genetic background, Table S1: Details of drought related markers used in the study, Table S2: Response of selected Iraqi rice cultivars to 10\% PEG, Table S3: Responses of selected Iraqi rice cultivars to drought stress (Pot experiment).

Author Contributions: Conceptualization, M.S. and B.W.Y.; Methodology, T.N.I.A.A. and M.K.; Software, T.N.I.A.A., M.K. and Q.M.I.; Validation, A.H. and Q.M.I.; Formal Analysis, B.-G.M and S.-U.L.; Resources, B.-W.Y.; Writing-Original Draft Preparation, M.K. and A.H.; Writing-Review \& Editing, Q.M.I. and A.H.; Supervision, B.-W.Y.; Project Administration, B.-G.M.; Funding Acquisition, B.-W.Y. All authors have read and agreed to the published version of the manuscript.

Funding: This work was supported by a grant from the Next-Generation BioGreen 21 Program (SSAC, Grant No., PJ01342501), Rural Development Administration, Korea.

Conflicts of Interest: The authors declare that they have no competing interests.

\section{References}

1. Awasthi, S.; Lal, J. Validation of SSR markers associated with drought tolerant QTLs in rice (Oryza sativa L.). Int. J. Sci. Footprints 2014, 2, 99-113.

2. Khush, G.S. What it will take to Feed 5.0 Billion Rice consumers in 2030. Plant. Mol. Biol. 2005, 59, 1-6. [CrossRef] [PubMed]

3. Jaleel, C.A.; Manivannan, P.; Wahid, A.; Farooq, M.; Al-Juburi, H.J.; Somasundaram, R.; Panneerselvam, R. Drought stress in plants: A review on morphological characteristics and pigments composition. Int. J. Agric. Biol. 2009, 11, 100-105.

4. Wilhite, D.A.; Pulwarty, R.S. Drought and Water Crises: Lessons Drawn, Some Lessons Learned, and the Road Ahead. In Drought and Water Crises: Integrating Science, Management, and Policy; CRC Press: Boca Raton, FL, USA, 2018; pp. 513-528.

5. Al-Faraj, F.A.; Al-Dabbagh, B.N. Assessment of collective impact of upstream watershed development and basin-wide successive droughts on downstream flow regime: The Lesser Zab transboundary basin. J. Hydrol. 2015, 530, 419-430. [CrossRef]

6. Al-Timimi, Y.K.; Al-Jiboori, M.H. Assessment of spatial and temporal drought in Iraq during the period 1980-2010. Int. J. Energ. Environ. 2013, 4, 291-302.

7. Lindsey, K.; Jones, M. Plant. Biotechnology in Agriculture; Open University Press: Berkshire, UK, 1989.

8. Buchanan, C.D.; Lim, S.; Salzman, R.A.; Kagiampakis, I.; Morishige, D.T.; Weers, B.D.; Klein, R.R.; Pratt, L.H.; Cordonnier-Pratt, M.-M.; Klein, P.E.; et al. Sorghum bicolor's Transcriptome Response to Dehydration, High Salinity and ABA. Plant. Mol. Biol. 2005, 58, 699-720. [CrossRef]

9. Poroyko, V.; Hejlek, L.; Spollen, W.; Springer, G.; Nguyen, H.; Sharp, R.; Bohnert, H.J. The Maize Root Transcriptome by Serial Analysis of Gene Expression1[w]. Plant. Physiol. 2005, 138, 1700-1710. [CrossRef]

10. Taheri, S. Effects of drought stress condition on the yield of spring wheat (Triticum aestivum) lines. Afr. J. Biotechnol. 2011, 10, 18339-18348. [CrossRef]

11. Serraj, R.; McNally, K.L.; Slamet-Loedin, I.; Kohli, A.; Haefele, S.; Atlin, G.; Kumar, A. Drought Resistance Improvement in Rice: An Integrated Genetic and Resource Management Strategy. Plant. Prod. Sci. 2011, 14, 1-14. [CrossRef]

12. Penna, S. Building stress tolerance through over-producing trehalose in transgenic plants. Trends Plant. Sci. 2003, 8, 355-357. [CrossRef]

13. Reddy, A.R.; Chaitanya, K.V.; Vivekanandan, M. Drought-induced responses of photosynthesis and antioxidant metabolism in higher plants. J. Plant. Physiol. 2004, 161, 1189-1202. [CrossRef]

14. Abid, M.; Ali, S.; Qi, L.K.; Zahoor, R.; Tian, Z.; Jiang, D.; Snider, J.L.; Dai, T. Physiological and biochemical changes during drought and recovery periods at tillering and jointing stages in wheat (Triticum aestivum L.). Sci. Rep. 2018, 8, 1-15. [CrossRef] 
15. Fukai, S.; Cooper, M. Development of drought-resistant cultivars using physiomorphological traits in rice. Field Crop. Res. 1995, 40,67-86. [CrossRef]

16. Xu, K.; Chen, S.; Li, T.; Ma, X.; Liang, X.; Ding, X.; Liu, H.; Luo, L.J. OsGRAS23, a rice GRAS transcription factor gene, is involved in drought stress response through regulating expression of stress-responsive genes. BMC Plant. Biol. 2015, 15, 141. [CrossRef]

17. Qin, F.; Sakuma, Y.; Tran, L.-S.P.; Maruyama, K.; Kidokoro, S.; Fujita, Y.; Fujita, M.; Umezawa, T.; Sawano, Y.; Miyazono, K.-I.; et al. Arabidopsis DREB2A-Interacting Proteins Function as RING E3 Ligases and Negatively Regulate Plant Drought Stress-Responsive Gene Expression. Plant. Cell 2008, 20, 1693-1707. [CrossRef] [PubMed]

18. Corrêa, L.G.G.; Riaño-Pachón, D.M.; Schrago, C.G.; Dos Santos, R.V.; Mueller-Roeber, B.; Vincentz, M. The Role of bZIP Transcription Factors in Green Plant Evolution: Adaptive Features Emerging from Four Founder Genes. PLoS ONE 2008, 3, e2944. [CrossRef]

19. Lata, C.; Muthamilarasan, M.; Prasad, M. Drought Stress Responses and Signal Transduction in Plants. In Elucidation of Abiotic Stress Signaling in Plants; Springer Science and Business Media LLC: Berlin, Germany, 2015; pp. 195-225.

20. Yamaguchi-Shinozaki, K.; Shinozaki, K. Transcriptional Regulatory Networks In Cellular Responses And Tolerance To Dehydration And Cold Stresses. Annu. Rev. Plant. Biol. 2006, 57, 781-803. [CrossRef]

21. Lafitte, R.; Blum, A.; Atlin, G. Using secondary traits to help identify drought-tolerant genotypes. In Breeding Rice for Drought-Prone Environments; IRRI: Laguna, Philippines, 2003; pp. 37-48.

22. Farooq, M.; Wahid, A.; Kobayashi, N.; Fujita, D.; Basra, S.M.A. Plant Drought Stress: Effects, Mechanisms and Management. In Sustainable Agriculture; Springer: Dordrecht, The Netherlands, 2009; Volume 29, pp. 153-188. [CrossRef]

23. Ni, J.; Colowit, P.M.; Mackill, D.J. Evaluation of genetic diversity in rice subspecies using microsatellite markers. Crop. Sci. 2002, 42, 601-607.

24. Okoshi, M.; Hu, J.; Ishikawa, R.; Fujimura, T. Polymorphic Analysis of Landraces of Japanese Rice using Microsatellite Markers. Breed. Res. 2004, 6, 125-133. [CrossRef]

25. Collins, N.C.; Tardieu, F.; Tuberosa, R. Quantitative Trait Loci and Crop Performance under Abiotic Stress: Where Do We Stand?: Table I. Plant. Physiol. 2008, 147, 469-486. [CrossRef]

26. Elmajid, A.; Omer, A.B. Characterization Of Drought Tolerance Traits In Selected Rice (Oriza Sativa L.) Genotypes Grown In Sudan Using Simple Sequence Repeat (Ssr) Markers. Master's Thesis, Jomo Kenyatta University of Agriculture and Technology, Juja, Kenya, 2018.

27. Singh, N.; Dang, T.T.M.; Vergara, G.V.; Pandey, D.M.; Sanchez, D.; Neeraja, C.N.; Septiningsih, E.M.; Mendioro, M.; Tecson-Mendoza, E.M.; Ismail, A.M.; et al. Molecular marker survey and expression analyses of the rice submergence-tolerance gene SUB1A. Theor. Appl. Genet. 2010, 121, 1441-1453. [CrossRef] [PubMed]

28. Kikuchi, S.; Satoh, K.; Nagata, T.; Kawagashira, N.; Doi, K.; Kishimoto, N.; Yazaki, J.; Ishikawa, M.; Yamada, H.; Ooka, H.; et al. Collection, Mapping, and Annotation of Over 28,000 cDNA Clones from japonica Rice. Science 2003, 301, 376-379. [CrossRef] [PubMed]

29. Jayashree, B.; Punna, R.; Prasad, P.; Bantte, K.; Hash, C.T.; Chandra, S.; A Hoisington, D.; Varshney, R.K. A database of simple sequence repeats from cereal and legume expressed sequence tags mined in silico: Survey and evaluation. Silico Biol. 2006, 6, 607-620.

30. Ichitani, K.; Namigoshi, K.; Sato, M.; Taura, S.; Aoki, M.; Matsumoto, Y.; Saitou, T.; Marubashi, W.; Kuboyama, T. Fine mapping and allelic dosage effect of Hwc1, a complementary hybrid weakness gene in rice. Theor. Appl. Genet. 2007, 114, 1407-1415. [CrossRef] [PubMed]

31. Gholizadeh, A. Heterologous Expression of Stress-Responsive DUF538 Domain Containing Protein and its Morpho-Biochemical Consequences. Protein J. 2011, 30, 351-358. [CrossRef] [PubMed]

32. Xia, H.; Zheng, X.; Chen, L.; Gao, H.; Yang, H.; Long, P.; Rong, J.; Lu, B.; Li, J.; Luo, L.J. Genetic Differentiation Revealed by Selective Loci of Drought-Responding EST-SSRs between Upland and Lowland Rice in China. PLoS ONE 2014, 9, e106352. [CrossRef]

33. Hirayama, T.; Shinozaki, K. Research on plant abiotic stress responses in the post-genome era: Past, present and future. Plant J. 2010, 61, 1041-1052. [CrossRef]

34. Singh, K. Transcription factors in plant defense and stress responses. Curr. Opin. Plant. Biol. 2002, 5, 430-436. [CrossRef] 
35. Shinozaki, K. Molecular responses to dehydration and low temperature: Differences and cross-talk between two stress signaling pathways. Curr. Opin. Plant. Biol. 2000, 3, 217-223. [CrossRef]

36. Joo, J.; Lee, Y.H.; Song, S.I. Overexpression of the rice basic leucine zipper transcription factor OsbZIP12 confers drought tolerance to rice and makes seedlings hypersensitive to ABA. Plant. Biotechnol. Rep. 2014, 8, 431-441. [CrossRef]

37. Aboukhadrah, S.; Abd Allah, A.; Gharib, H.; Sakran, R.M. Effect of Soil Water Deficit on Yield and Its Components at The Different Growth Stages in Rice (Oryza sativa). Egyptian J. Agro. 2015, 37, 79-92.

38. Kim, T.; Hur, Y.-J.; Han, S.-I.; Cho, J.-H.; Kim, K.-M.; Lee, J.-H.; Song, Y.-C.; Kwon, Y.-U.; Shin, D. Drought-tolerant QTL qVDT11 leads to stable tiller formation under drought stress conditions in rice. Plant. Sci. 2017, 256, 131-138. [CrossRef] [PubMed]

39. Casartelli, A.; Riewe, D.; Hubberten, H.M.; Altmann, T.; Hoefgen, R.; Heuer, S. Exploring traditional aus-type rice for metabolites conferring drought tolerance. Rice 2018, 11, 1-16. [CrossRef] [PubMed]

40. Wade, L.J.; McLaren, C.G.; Quintana, L.; Harnpichitvitaya, D.; Rajatasereekul, S.; Sarawgi, A.K.; Kumar, A.; Ahmed, H.U.; Sarwoto; Singh, A.K.; et al. Genotype by environment interactions across diverse rainfed lowland rice environments. Field Crop. Res. 1999, 64, 35-50. [CrossRef]

41. Ubaidillah, M.; Faperta, M.; Kim, K.-M. Identification of phytohormone changes and its related genes under abiotic stresses in transgenic rice. BIOCELL 2019, 43, 215-224. [CrossRef]

42. Kaneda, C. Breeding and Dissemination Efforts of "NERICA". Jpn. J. Trop. Agric. 2007, 51, 145-151.

43. Futakuchi, K.; Fofana, M.; Sie, M. Varietal Differences in Lodging Resistance of African Rice (Oryza glaberrima Steud.). Asian J. Plant. Sci. 2008, 7, 569-573. [CrossRef]

44. Badro, H.; Furtado, A.; Henry, R.J. Relationships between Iraqi Rice Varieties at the Nuclear and Plastid Genome Levels. Plants 2019, 8, 481. [CrossRef]

45. Huang, J.; Wang, M.-M.; Jiang, Y.; Bao, Y.; Huang, X.; Sun, H.; Xu, D.; Lan, H.-X.; Zhang, H. Expression analysis of rice A20/AN1-type zinc finger genes and characterization of ZFP177 that contributes to temperature stress tolerance. Gene 2008, 420, 135-144. [CrossRef]

46. Hoagland, D.R.; Arnon, D.I. The water-culture method for growing plants without soil. Circular. Calif. Agric. Experim. Stn. 1950, 347, 32.

47. Grimault, A.; Gendrot, G.; Chamot, S.; Widiez, T.; Rabillé, H.; Gérentes, M.-F.; Creff, A.; Thévenin, J.; Dubreucq, B.; Ingram, G.; et al. ZmZHOUPI, an endosperm-specific basic helix-loop-helix transcription factor involved in maize seed development. Plant J. 2015, 84, 574-586. [CrossRef] [PubMed]

48. Jiang, Y.; Liang, G.; Yu, D. Activated Expression of WRKY57 Confers Drought Tolerance in Arabidopsis. Mol. Plant. 2012, 5, 1375-1388. [CrossRef] [PubMed]

49. Ses, I. Standard Evaluation System; International Rice Research Institute: Manila, Philippines, 2002; pp. 11-30.

50. De Datta, S.; Malabuyoc, J.; Aragon, E. A field screening technique for evaluating rice germplasm for drought tolerance during the vegetative stage. Field Crop. Res. 1988, 19, 123-134. [CrossRef]

51. Yang, P.-M.; Huang, Q.-C.; Qin, G.-Y.; Zhao, S.-P.; Zhou, J.G. Different drought-stress responses in photosynthesis and reactive oxygen metabolism between autotetraploid and diploid rice. Photosynthetica 2014, 52, 193-202. [CrossRef]

52. Khan, M.A.; Asaf, S.; Khan, A.L.; Adhikari, A.; Jan, R.; Ali, S.; Imran, M.; Kim, K.-M.; Lee, I.-J. Halotolerant Rhizobacterial Strains Mitigate the Adverse Effects of $\mathrm{NaCl}$ Stress in Soybean Seedlings. BioMed Res. Int. 2019, 2019, 1-15. [CrossRef]

53. Khan, M.; Imran, Q.M.; Shahid, M.; Mun, B.-G.; Lee, I.-J.; Khan, M.A.; Hussain, A.; Lee, I.-J.; Yun, B.-W. Nitric oxide- induced AtAO3 differentially regulates plant defense and drought tolerance in Arabidopsis thaliana. BMC Plant. Biol. 2019, 19, 602-619. [CrossRef]

54. Revalska, M.; Vassileva, V.; Zechirov, G.; Iantcheva, A. Is the auxin influx carrierLAX3essential for plant growth and development in the model plantsMedicago truncatula, Lotus japonicusand Arabidopsis thaliana? Biotechnol. Biotechnol. Equip. 2015, 29, 786-797. [CrossRef]

55. Al-Ansari, N.; Ali, A.; Knutsson, S. Present Conditions and Future Challenges of Water Resources Problems in Iraq. J. Water Resour. Prot. 2014, 6, 1066-1098. [CrossRef]

56. da Cruz, R.P.; Milach, S.C.K. Tolerância ao frio no estádio de germinação em arroz: Métodos de avaliação e caracterização de genótipos. Sci. Agric. 2004, 61, 1-8.

57. Krishnasamy, V.; Seshu, D.V. Seed Germination Rate and Associated Characters in Rice. Crop. Sci. 1989, 29, 904-908. [CrossRef] 
58. Singh, B.N.; Mackill, D.J. Genetics of leaf rolling under drought stress. In Rice Genetics Collection; World Scientific Pub Co Pte Ltd.: Singapore, 2008; pp. 159-166.

59. Madabula, F.P.; Dos Santos, R.S.; Machado, N.; Pegoraro, C.; Kruger, M.M.; Da Maia, L.C.; De Sousa, R.O.; De Oliveira, A.C. Rice genotypes for drought tolerance: Morphological and transcriptional evaluation of auxin-related genes. Bragantia 2016, 75, 428-434. [CrossRef]

60. Okçu, G.; Kaya, M.D.; Atak, M. Effects of salt and drought stresses on germination and seedling growth of pea (Pisum sativum L.). Turkish J. Agric. Forestry 2005, 29, 237-242.

61. Abegunewardene, N.; Schmidt, K.-H.; Vosseler, M.; Dreher, M.; Keller, T.; Hoffmann, N.; Veit, K.; Petersen, S.E.; Lehr, H.; Schreiber, W.G.; et al. Local Transient Myocardial Liposomal Gene Transfer of Inducible Nitric Oxide Synthase Does Not Aggravate Myocardial Function and Fibrosis and Leads to Moderate Neovascularization in Chronic Myocardial Ischemia in Pigs. Microcirculation 2010, 17, 69-78. [CrossRef] [PubMed]

62. Manschadi, A.M.; Hammer, G.L.; Christopher, J.T.; Devoil, P. Genotypic variation in seedling root architectural traits and implications for drought adaptation in wheat (Triticum aestivum L.). Plant. Soil 2007, 303, 115-129. [CrossRef]

63. Franco, J.; Bañón, S.; Vicente, M.J.; Miralles, J.; Martínez-Sánchez, J.J. Review Article:Root development in horticultural plants grown under abiotic stress conditions - a review. J. Hortic. Sci. Biotechnol. 2011, 86, 543-556. [CrossRef]

64. Gowda, V.R.; Henry, A.; Yamauchi, A.; Shashidhar, H.E.; Serraj, R. Root biology and genetic improvement for drought avoidance in rice. Field Crop. Res. 2011, 122, 1-13. [CrossRef]

65. Rabello, A.R.; Guimarães, C.M.; Rangel, P.H.N.; Da Silva, F.R.; Seixas, D.; Souza, E.M.; Brasileiro, A.C.M.; Spehar, C.R.; Ferreira, M.E.; Mehta, A. Identification of drought-responsive genes in roots of upland rice (Oryza sativa L). BMC Genom. 2008, 9, 485. [CrossRef]

66. Hadiarto, T.; Tran, L.-S.P. Progress studies of drought-responsive genes in rice. Plant. Cell Rep. 2011, 30, 297-310. [CrossRef]

67. Dubouzet, J.G.; Sakuma, Y.; Ito, Y.; Kasuga, M.; Dubouzet, E.G.; Miura, S.; Seki, M.; Shinozaki, K.; Yamaguchi-Shinozaki, K. OsDREB genes in rice, Oryza sativa L., encode transcription activators that function in drought-, high-salt- and cold-responsive gene expression. Plant J. 2003, 33, 751-763. [CrossRef]

68. Jakoby, M.; Weisshaar, B.; Dröge-Laser, W.; Vicente-Carbajosa, J.; Tiedemann, J.; Kroj, T.; Parcy, F. bZIP transcription factors in Arabidopsis. Trends Plant. Sci. 2002, 7, 106-111. [CrossRef]

69. Kraus, T.E.; McKersie, B.D.; Fletcher, R.A. Paclobutrazol-induced Tolerance of Wheat Leaves to Paraquat May Involve Increased Antioxidant Enzyme Activity. J. Plant. Physiol. 1995, 145, 570-576. [CrossRef]

70. Sedeek, S.E.M.; El-Namaky, R.A.; Hammoud, S.A.A.; El-Habet, H.B. Genetical Studies On Root System And Yield And Its Components Traits Under Water Limit Condition In Rice (Oryza sativa L.). J. Agric. Chem. Biotechnol. 2012, 3, 447-460. [CrossRef]

71. Hasan, M.; Bhuiyan, M.; Begum, S.; Raffi, S.; Razia, S. Morphological and molecular characterization of some NERICA mutant lines under drought condition. Progress. Agric. 2015, 26, 15-21. [CrossRef]

Publisher's Note: MDPI stays neutral with regard to jurisdictional claims in published maps and institutional affiliations.

(C) 2020 by the authors. Licensee MDPI, Basel, Switzerland. This article is an open access article distributed under the terms and conditions of the Creative Commons Attribution (CC BY) license (http://creativecommons.org/licenses/by/4.0/). 